\title{
POSTCOLONIAL ANALYSIS ON MULTATULI'S MAX HAVELAAR
}

\author{
Herminus Efrando Pabur
}

\begin{abstract}
This work aims at sharing a postcolonial analysis on the content and the message in Max Havelaar written by Mulatuli in 1859 in Belgia and then published in Dutch in 1860. Max Havelaar could be assumed as a postcolonial literary work. Besides applying the postcolonial theory, the anthropology theory is also considered being used in the analysis process. The finding shows that Max Havelaar is clearly a postcolonial literary work. Despite basing on its year of publication and place of publication, Max Havelaar is hard to be categorized as a postcolonial literary work. However, its content, message, and author's background, Max Havelaar can be viewed as a postcolonial literary work. The finding also reveals that Max Havelaar has a unique and strong characteristic namely the ability to move the sense of humanity of its readers especially for those are facing colonialization.
\end{abstract}

\section{Keywords: Max Havelaar, Postcolonial Literature.Multatuli}

\section{Introduction}

Nowadays literature becomes more interesting. It is because literature offers many things: moral value, new knowledge and even entertainment. By the benefit given by literature many people started to like literature. An important point to be noted regarding the literature (literary works: Poem, Novel and Drama) is its function as 'mirror' (Gann, 2012). It means that literary works reflect the life of people or reflect the society. Maru in his dissertation entitled Puritanism in American Presidents 'Mark of Power: A Study on The Inaugural Addresses from Reagan to Obama (2013) quoting Tate stated, "Many of the forces at work in the fiction are clearly social origin" (p.38). It elaborates that the birth of a literary work is not apart from the social realities. The portrait of society in the work may reflect the social experience of a certain society. Thus, it usually correlates to themes raised in literary works.

Theme in a literary work is important because it is the main idea in the literary work. Griffith (1986) states: "Theme is the central idea in the work whether fiction, poetry, or drama. It is the comment that the work makes on human condition. It deals with four general areas of human experiences, the nature of humanity, the nature of society, the nature of human kind of relationship to the world, and the nature of four ethical responsibilities." This notion tell us that theme in a literary works try to describe how human is, how society is, and the world is. These themes might be nationalism, Racism, Gender, and even culture.

The themes such as nationalism, Racism, and Culture can be found easily in postcolonial literature. Postcolonial literature can be simply understood as the literary works emerged out after the imperialism and colonialism end. However, Bamghose (2013) argues that postcolonial literature had existed before the term postcolonial literature is used widely. However Vogel (2012:101) noted that, "The terms 'colonial' and 'post-colonial' are understood differently in The Empire Writes Back (1989), whose authors suggest that the term 'post-colonial' should refer to all cultures affected by imperial expansion - from the beginnings of colonization to the present day." Knowing that the term postcolonial has a bigger scope, we have to examine carefully the postcolonial literature by knowing the tendency brought.

Postcolonial literature has a tendency to writing back the history (Cuddon, 2013: 551). Writing back the history is a tendency to make the colonized countries as a historical subject and 
not the historical object of colonial discourse. It is also a strategy to fight back the Eurocentric that happened in colonized countries and to resist the imperialism effect in colonized society. Postcolonial literature also can be seen as an intellectual movement that tries to correct the stereotypical opinion which is made by the false image of western discourse towards the colonized countries. The tendency and the aims mentioned before can be seen clearly in Multatuli's Max Havelaar. So that we can conclude that Max Havelaar is a postcolonial literary work.

Max Havelaar is a novel written by Eduard Douwes Dekker under his pen name Multatuli. This novel is published in 1860 in Netherlands. At first this novel entitles Max Havelaar: Or the Coffee Auctions of the Dutch Trading Company (Dutch: Max Havelaar, of de koffi-veilingen der Nederlandsche Handel-Maatschappij) however since this novel is a very famous work many translators used Max Havelaar as the title of the book. This novel is written by Multatuli after serving Dutch as a civil servant for 18 years in Indonesia (Dutch East Indies). This novel showed a great impact in changing the colonial policies made by Dutch and opened the eyes of the people in Netherlands about the abuses of power under the colonial system in the nineteenth and early twentieth century. This novel mainly tells about Max Havelaar, the protagonist, who tries to battle against a corrupt and cruel colonial government system in Lebak (a residency in Java).

Max Havelaar written by Multatuli indeed brought many themes such as struggles for colonized people, slavery, exploitations and cruelties of colonizer, forced labor, pain faced by the colonized and even romance-tragedy. These themes then can be found in the novel and manifested in the stories in the novel. Based on the ideas brought in the novel, the characteristics of the novel, the spirit and the message brought in the novel, and based on themes, this novel is indeed a postcolonial literary work. Coming from this fact, I will try to give a postcolonial analysis on the novel written by Multatuli, Max Havelaar. The analysis will be focused more on the characteristics of postcolonial literature and the message brought in the novel.

\section{Postcolonial Literature: Studies and Theories}

Talking about postcolonial literature we have to face some similar terms such as postcolonial studies, postcolonial theory and postcolonialism. Are there some differences among them? Cuddon (2013: 550) states that the term postcolonialism is used to cover the terms postcolonial studies, postcolonial theory and postcolonial literature. Postcolonial studies are the studies based on the main aspects of colonialism and their pervasive effects which have persisted remarkably even after then end of the colonial rule (Tepeciklioglu, 2012). Postcolonial literature or postcolonial theory is a literature theory or critical approach that deals with literature produced in countries that were once, or are now, colonies of other countries and even literature written by citizens of colonizing countries (www.decolonize.org). Since, the postcolonialism has a broader scope than postcolonial literature; it is better to use the term of postcolonialism instead of postcolonial literature in order to have a various explanations about postcolonial literature and theory. Furthermore the term postcolonialism covers the term postcolonial literature.

Postcolonialism is used to analyze or to criticize the literary works produced in postcolonial period. Abrams (1990: 236) states that postcolonialism is "critical analysis of the history, culture, literature and modes of discourse that are specific to the former colonies of English, Spain, France, and other European imperial powers. These studies have focused especially on the third world countries in Africa, Asia, the Caribbean island, and South America." Coming from this notion, the use of postcolonialism is not limited to the literary critics but is also used to analyze the history and culture. However, this term sometimes used to examine the texts in postcolonial period. 
In line with Abrams, Cuddon (2013: 550) states, "Postcolonialism is an interdisciplinary academic field devoted to the study of European colonialism and its impact on the society, culture, history and politics of the formerly colonized regions..." It indicates that postcolonialism is used widely in many academic fields to understand the phenomena in society of postcolonial period. Furthermore, Postcolonialism is a body of academic study that draws on critical theory to understand the loss of power, identity, and culture when a group of people is dominated by a conquering force. (Khanal, 2012: 2). This term also used to examine the history, political system, linguistics, and literary works in postcolonial period. In short, literature field is not the only field where the term postcolonialism is used.

Since the use of term postcolonialism is too general, there is an immense diversity of postcolonialism theory which focus on different issues such as literature, art, music, linguistics, slavery, migration, discrimination, historiography, and discusses different kinds of subjugation like racism, gender, nationalism and identity (Tepeciklioglu, 2012: 1). It means that the themes such as racism, nationalism and identity are common to be found in postcolonial literature. These themes are common because postcolonial literature sets out in one way or another to resist colonialist perspective (Mondal, 2012: 2965). In short postcolonial literature is used to make the colonized aware of their culture, national identity, and races.

As a study, Postcolonialism is the study of the changes of cultures and politics and it has these three stages: 1) Social, political, cultural and psychological inferiority on colonized people by Westerner's; 2) Desire for power in ethnic, political and cultural areas; 3) Awareness of hybridity and double identity (Fatima, Jamil, and Hanif, 2015: 40). Coming from these three stages, it can be see that postcolonialism also examine the dominance of western in colonized countries. The issues such as national identity are also important in postcolonial studies, since many postcolonial writers tried to 'writing back' the history.

From the literature point of view, postcolonialism involves the challenge to colonial ways of knowing, 'writing back' in opposition to such views (Mondal, 2012: 2965). He tried to tell that literary works in postcolonial period is used to resist the colonial effects that influenced the colonized countries by 'recreating' the history. The term recreating refers to the ideas show more heroic side of colonized countries. Mondal (2012: 2965) then argues, "It does not define a radically new historical era, nor does it herald a brave new world where all the ills of the colonial past have been cured." It means that literary works in postcolonial period have a purpose to show that they have overcome the colonial effects and have gained the independence. It is the reason why many postcolonial writers focus on common themes such as struggle for independence and national identity (www.decolonize.org).

Postcolonial literature and criticism appeared during and after many countries have gained or were struggling for independency (Dizayi, 2015: 1000). It means that nationalism and local identity are central issues in postcolonial literature. These themes are lifted up in order to make the awareness of nationalism grow so the people of colonized countries have the motivation to struggle for their independency. Dizayi (2015: 1000) then explained that other themes such as race, gender, ethnicity, identity and culture can be used to support the central theme.

Postcolonial literature has frequently been accompanied by the demand for an entirely new or wholly recovered 'reality'; free all colonial taint (Ashcroft, Griffiths and Tiffin, 2003: 95). It means that the postcolonial literature use freedom as an 'offer' for the colonized people or it can be said that freedom is the result of their struggling. However, the concern of postcolonial literature focuses on the effects of colonialism on cultures and communities (Dizayi, 2015: 1000). Furthermore, postcolonial literature often addresses the problems and consequences of the decolonization of a country, especially questions relating to the political and cultural independence of formerly subjugated people, and themes such as racialism and colonialism (www.wikipedia.org). 
Although many postcolonial writers used nationalism as the main theme, the influences of colonialism still affect them. It can be seen in the fact that many postcolonial writers write in English and not in their local language. Ashcroft, Griffiths and Tiffin (2003: 95) then add, "Postcolonial cultures are inevitably hybridized, involving a dialectical relationship between European ontology and epistemology and the impulse to create or recreate independent local identity." By this notion it is known that the ideas of nationalism, independency and national identity was not developed originally by the postcolonial writers, the European influences also take place in forming their ideas about freedom, nationality, etc.

As a literary theory, postcolonialism can be understood as an investigation "which traces European colonialism of many regions all over the world, its effects on various aspects of the lives of the colonized people in general, and its manifestations in Western literary and philosophical heritage in particular throughout the nineteenth and the twentieth centuries, in addition to the emergence of the literature of opposition and resistance in the ex-colonies" (Hamadi, 2014: 39). By this notion there is an interesting fact noted, it is the fact that postcolonial literature is not limited to the literary works written by the colonized people but also the western literary works influenced by the colonized literary work. The same as other theory of postcolonial literature, Hamadi wanted to emphasis the tendency to resist the colonizer's influences in colonized country by using literary work as the medium.

\section{The Characteristics}

Another important point to be discussed in this work is the characteristics of postcolonial literature. I think it is important in order to understand the issues brought by the writers, the tendencies in the works and even its effects. Abrams (1999) explains that there are three important characteristics of postcolonial literature. Quoted form his work, A Glossary of Literary Term (Seventh Edition), he states the three characteristics of postcolonial literature as follows:

1) "The rejection of the master-narrative of Western imperialism - in which the colonial other is not only subordinated and marginalized, but in effect deleted as a cultural agency - and its replacement by a counter-narrative in which the colonial cultures fight their way back into a world history written by Europeans..." (p. 136)

2) "An abiding concern with the formation, within Western discursive practices, of the colonial and postcolonial "subject," as well as of the categories by means of which this subject conceives itself and perceives the world within which it lives and acts. The subaltern has become a standard way to designate the colonial subject that has been constructed by European discourse and internalized by colonial peoples who employ this discourse; "subaltern" is a British word for someone of inferior rank, and combines the Latin terms for "under" (sub) and "other" (alter). A recurrent topic of debate is how, and to what extent, a subaltern subject, writing in a European language, can manage to serve as an agent of resistance against, rather than of compliance with, the very discourse that has created its subordinate identity." (p. 136 - 137)

3) "A major element in the postcolonial agenda is to disestablish Eurocentric norms of literary and artistic values, and to expand the literary canon to include colonial and postcolonial writers..." (p. 137)

Coming from the three characteristics above, it can be seen that postcolonial literature has a tendency to resist the European dominance. In this case, Abrams tries to emphasis the tendency to rewriting the western texts. The issue regarding the local identity and nationalism also can be seen in the postcolonial literature. In short, postcolonial literatures seek to reclaim selfrepresentation from stereotypical portrayals in colonial literatures and colonial discourses, and to 
do so they often use the 'writing back' paradigm, or a rewriting of Western 'master' texts (Cuddon, 2013: 551).

Coming from the theories above, there are some important points about the characteristics of postcolonial literature that can be discussed in this part. These important points are:

\section{1) Tendencies of writing back}

There is a saying, "Winner writes the history." It means that the strong side will always dominate the weak side and the strong side will always have the control. This fact can be seen during colonial year: the Europeans have the dominance over the third world countries. It is also affect the literary works. Mohammadzadeh (2010:1024) states, "During the colonial period written text favored the Europeans and their superiority over the non-Europeans. It was the system of power that determines the representations." It indicates that the colonizer have the power in every aspect of colonized, in other words they control the colonized. In this era the colonized people are exploited: becoming the slaves for the colonizer.

His opinion also emphasizes the superiority of colonizer of the colonized. He then argues:

Thus, in oriental discourse the Europeans were portrayed as "masculine", "democrat", "rational", "moral", "dynamic", and "progressive". Otherwise, since the writing was under the direct control of the Europeans the non-Europeans were described as "voiceless", "sensual", "female", "despotic", "irrational", and "backward". (p. 1024)

Coming from the notion above, it can be clearly that the colonizers wrote the history for themselves. It is indicated by the description given to the colonizers and colonized. There is a big gap in describing these two sides. However, the big gap did not limit the interaction between these two sides: there is a relationship built between these two sides although the colonizers are in the favored side. This relationship then emerged out the postcolonial literature.

The history then changed when the colonized countries obtained their independency. They started to fight back the Eurocentric by using literary works. It is what the writer understands as 'writing back.' Mohammadzadeh (2010:1025) explains as follows:

"However, the colonized people after obtaining their dependency, who acknowledged the importance of their identity and who learned not to be embarrassed about their culture and past, started to create their own text called postcolonial literature. Then, postcolonial text began to abolish the Eurocentric assumptions created by the Europeans, although the colonized had not the privilege to break the European domination and to portray the Europeans the same way they were illustrated through the colonial period. To put it more precisely, they have had the opportunity to present Europeans as "immoral", "irrational", and "sensual", just as they were pictured during the colonial period. Moreover, the colonized, having been neglected for a long time, and tolerating the suffering for decades, upon starting to write the text began to imitate the colonizer." (p. 1025)

The quotation above indicates that the colonized started to 'revenge' their pains in the past. They started to counter the Eurocentric by using cruel descriptions towards colonizers. The interesting part is the tendency to imitating European text, or it can be said "colonized-centered". They want to show the world that they are the suffered ones. It can be assumed this is the way to gain world sympathy or the way to make all the colonized countries feel the same so they can start to fight back the European through literary works.

Furthermore, since throughout the colonial period and the aftermath, the west had cultural and economic hegemony over the non-Europeans through orientalists' discourse, the will to writing back the history become bigger. Khanal (2012: 1) argues, "The primary contribution of postcolonial theory is to challenge the traditional value system and epistemology that fuels western philosophy, politics, education, and social-economic theory." It indicates that 
colonized countries are sick of the colonizers and their influences. They want to challenge the European norms in order to bring their norms up. Bamghose (2013: 35) also argues, "Postcolonial theory is a body of discourse that responds to colonialism and its aftermath in the Empire. It is a form of race and ethnicity-bound discourse, which counters the 'centre' in order to give the 'margin' its own true voice and identity in the imperial order of things." In short, postcolonial literature are exist to resist the Eurocentric and to grow the awareness of national identity.

Another important idea is proposed by Waqar (2016). He tries to show us that there is a different strategy between African writers and Caribbean Writers in writing back the history. He explains the idea by saying:

"In the works of African writers like Achebe and Ben Okri, the tone is quiet and controlled and the themes analyzed consist of the colonial and postcolonial history and the disorientation in the African politics on account of intolerance, lack of education and unpreparedness of the African nations to deal with the post- independence challenges. Whereas the tone in the Caribbean literature by Walcott, Wilson Harris, Brathwaite is both controlled and urgent. Their writings center on the postcolonial strategies of rewriting history to reclaim the past to understand and accept it in order to repossess home and make positive progress in life in the Caribbean where the Africans were brought in chains to work on the sugar plantations." (p. 117)

These different strategies then make the postcolonial literature richer in case of style. Although there are different styles the issue brought in the postcolonial literary works are still the same: seeking for the independence. The differences mentioned before can be very useful in doing research regarding postcolonial literature.

\section{2) The concept of other}

Another important characteristics regarding postcolonial literature is the concept of 'other.' While reading some references to make this work, the writer met many opinions regarding this concept. Many books and academic journals mention the concept of 'other' when we search the postcolonial theory. This concept mainly tells about the view that the colonized countries and all their aspect are inferior, that is why they are called as 'other.'

The concept of other mainly refers to the superiority of Europeans over the colonized countries. Khanal (2012: 1-2) argues, "Such traditional thought is embedded in the sense of superiority demonstrated historically by Europe and the United States in encountering the people of other countries. It also tends to portray other cultures as an undifferentiated mass of "other" people; setting forth an "us-them" dichotomy that arises from the interaction of the colonizer and the colonized - the generalized "'other"." This notion wants to show us that the colonizers think they are superior in culture, politics and economic. The inferior ones then are described as 'other' since they are different with the colonizers. Furthermore, it also indicates the gap between the colonized and the colonizers.

The concept of other comes from the thought that the cultures besides western culture are different. Guven (2013: 80) examines:

"The colonizers consider that the culture of their ancestors was extremely civilized and that is why they define native people as savage or undeveloped. In other words, the colonizers see themselves as superior to the colonized people. In addition to this, colonizers think that they set up examples for the colonial people, so the colonized people "were considered 'other', different, and therefore inferior to the point of being less than fully human" (Tyson 420)" (p. 80)

The Europeans had in their mind that their culture is richer than other culture, so they feel superior. This idea is the same with the idea pointed out by Fatima, Jamil, and Hanif (2015: 40) that Europeans and colonized Africans regard one another. The Europeans think colonized peoples as inferior as well as "Others". The colonizers think that their native culture is rich so 
they represent colonized people as savages. However, Fatima, Jamil, and Hanif (2015: 41) also note, "...when Europeans find or get freedom from European restraints, their morality destroys and deteriorates to make trade gains of the subject races." It indicates that not all the Europeans feel themselves superior over other countries.

The concept of other also rises because the view of civilized and uncivilized to show that western sides are better than other side. Hamadi (2014) as influenced by Said theory tries to explain this notion by stating:

"Said's theory of postcolonialism is mainly based on what he considers the false image of the Orient or the East that has been fabricated by western explorers, poets, novelists, philosophers, political theorists, economists, and imperial administrators since Napoleon's occupation of Egypt in 1798. According to Said, these have always shown the Orient as the primitive, uncivilized "other", in an attempt to create it as the contrast to the advanced and civilized West." (p. 40)

By this notion, Hamadi wanted to emphasize that superiority of western is consider as a false image to make them as the right one. This false image then caused the colonized people as the uncivilized people. It also make western feel superior and then start to exploit and colonize the other people outside of Europe and even make them as a slaves.

\section{3) Question about Identity}

Previously as stated by Bamghose (2013) that postcolonial literature tries to show the true voice of the 'marginal' people in Imperialism era. Coming from this notion, I assume that the question about the national identity or the will for seeking the identity is also the characteristic of Postcolonial literature. The question about identity rises because the influence of Europe towards the colonized countries. Fatima, Jamal, and Hanif (2013:40) also argues, "Postcolonialism analyzes the modes of cultural perception and ways of viewing and being viewed. It describes the way the subaltern peoples are exploited by colonial rule and are represented in literary cannon." Bamghose (2013: 35) then add, "Postcolonial theory develops out of colonial and neo-colonial experiences in the worlds that have witnessed oppression in its old state and are still going through its hurdles in its new form." These notions indicate the will for seeking their identity is caused by the sick feeling of Imperialism brought by Europeans. We also have to note that postcolonial literature questions about Western dominance of power and knowledge (Bamghose, 2013: 35). Questioning western dominance indicates the awareness of their local identity. This fact can be seen in the literary works of postcolonial period which emphasis on some central themes such as nationalism.

\section{4) Alterity}

Alterity is also a characteristic of postcolonial literature. Alterity means the condition where the culture of colonized and colonizers incorporate each other. In explaining this term, Cuddon (2013) explains Alterity as

"A term denoting difference, employed to distinguish between notions of the 'other' as opposed to the 'self'. Levinas first extrapolated the concept to incorporate cultural 'selves' and 'others'. By extension, the term is now used widely in postcolonial discourse to refer to the ways in which disparate cultures, nations and religions both perceive and represent one another. In this sense, alterity can describe the process and rationale by which cultures perceived as 'marginal', whether by dint of race, gender or class, are subordinated to the dominant culture." (p. 27)

It means that in some literary works of postcolonial period, it can be seen that there is culture assimilation. Bamghose (2013: 36-37) even said, "Post-colonial literatures are as a result of this interaction between imperial culture and the complex of indigenous cultural practices. As a consequence, post-colonial theory has existed for a long time before the particular name was used to describe it... Postcolonial theory queries the assumption of universalism through which the West maintains its hegemony, and it maintains the 'alterity' or otherness of the margin 
through 'hybridity'." It indicates that every literary works in postcolonial period contain an imperial portrait as the result of cultures interaction.

\section{Postcolonial Period}

Before discussing the postcolonial period, it is important to know the origin of postcolonial literature. It is believed that it comes from Britain's colonies in the Caribbean, Africa and India (www.decolonize.org). In addition, Abrams (1999) notes that postcolonial literature also comes from former colonies of Spain, France and other European imperial powers. This fact indicates that postcolonial literature is a consequence of colonialism (Kanalemang, 2013).

The term postcolonial can be generally understood as the era after colonial era (post means after). However, the background where these contexts reside often stresses the 'post' in postcolonial and assume the end of the conditions of colonization and imperialism, the reality evidenced by postcolonial theory is to the contrary (Khanal, 2012: 2). This idea is then explored more by Shohat (1992) by arguing:

"Since the "post" in the "post-colonial" suggests "after" the demise of colonialism, it is imbued, quite apart from its users' intentions, with an ambiguous spatio-temporality. Spreading from India into Anglo-American academic contexts, the "post-colonial" tends to be associated with Third World countries which gained independence after World War II. However, it also refers to the Third World diasporic circumstances of the last four decades - from forced exile to "voluntary" immigration - within First World metropolises." (p. 102)

It means that the postcolonial literary works do not merely come from the Third World countries; it is because we have to consider the fact that there are some colonized people that immigrate to other countries. The immigrated people then make their own literary works to describe effects of imperialism and colonialism. Thus, the term postcolonial cannot be understood easily as the condition after the Third world begin to gaining their independency although the general opinion say it is.

The term postcolonialism first emerged out in late of 1940s, in the years following the Word War II when decolonization resulted in the emergence of newly independent nation-states (Roy, 2008: 317). Cuddon (2013: 551) states, "The term post-colonialism was first used by historians after the Word War II to refer chronologically to the post-independence period." It means that this term was generally used to be described the era when the colonialism has ended, in short after independence era (Kanalemang, 2013; Ashcroft, Griffiths and Tiffin, 2007). Furthermore this era was indicated by the emergence of the new-word nation or third world countries in Asia, Africa, the Caribbean island and South America.

In 1950s the term postcolonialism was used by the literary critics as an oppositional reading practice to study the effect of colonial representation in literary text (Cuddon, 2013: 551). However, another source argues that it was used as literature critical toolbox in 1970s (www.decolonize.org). Ashcroft, Griffiths and Tiffin (2007: 168) also advocate the notion that postcolonialism is used as literature critics in 1970s by stating, "From the late 1970 the term (postcolonialism) has been used by the literary critics to discuss the various effects of colonization." In the late 1970s this term emerged out within literary studies as the revolution 'theory' was extended to encompass the cultural, political and economic legacy of empire and its aftermath (Childs and Fowler, 2006: 138). It means that the literary works emerged out in postcolonial period is used to resist the colonial influences or to escapes from the image of colonization.

This term then become very popular in the 1980s and was used to identify societies and culture where the colonial rule had formally ended (Roy, 2008: 317). It means that this term is not only used in literature fields but widened in some discipline fields such as sociology and 
anthropology. However the term postcolonialism can be seen as a genre in a literature as Golden (2015) notes that numerous novelists, dramatists and poets have been marketed as postcolonial writers since 1980s. Another important point to be noted is the idea that the colonial rule has formally ended which means many countries had gained their independence. Abrams (1999: viii) then argues that postcolonial studies began in 1990. Although there are many opinions regarding the emergence of the term postcolonialism, we have to note that this term is not only used in literature field but used in many fields so the difference opinion regarding its rising is normal.

\section{The Misunderstanding of Postcolonial Literature}

As explained above, we can see that there are many opinions regarding the emergence of postcolonialism as well as the postcolonial literature. These different opinions lead us the misunderstanding about postcolonial literature. The first misunderstanding is the general opinion that postcolonial literature merely comes from the colonized countries that faced imperialism of western. This general opinion may come because there are many literary works come from the colonized countries. However we also have to note that postcolonial literature is also indicated by the themes brought in it. Vogel (2012: 100) examines, "We must remember, however, that postcolonial literature encompasses not only those works which were created after the end of the Empire, but also all those works which discuss and problematize the issue of relationships between the colonizer and the colonized — and in particular those masterpieces which offer an alternative to 'canonized' colonial fiction." By this notion we can conclude that a literary works categorized as a postcolonial literature because the issues brought in the works.

The issues brought in postcolonial literature are aimed to make the reader feel the experiences of colonized countries. Boehmer (1995) states:

"To give expression to colonized experience, postcolonial writers sought to undercut thematically and formally the discourses which supported colonization - the myths of power, the race classifications, the imagery of subordination. Postcolonial literature, therefore, is deeply marked by experiences of cultural exclusion and division under empire. Especially in its early stages it can also be a nationalist writing. Building on this, postcoloniality is defined as that condition in which the colonized seek to take their place, forcibly or otherwise, as historical subjects." (p. 3)

In order to make the reader feel the hardness during the Imperialism era the postcolonial writers tried to described the colonizers as the cruel one (Mohammadzadeh, 2010). The main emphasis of the postcolonial literature is also laid on the themes in the works in order to make the colonized as the historical subject and not the historical object.

The second misunderstanding is the notion that postcolonialism is an era. We have to understand that postcolonialism is not merely an era after the imperialism and postcolonialism ended. Bamghose (2013) examines:

"Post-colonialism possesses a bi-partite nature. First, it is an intellectual movement that attempts to correct the stereotypical assumptions foisted on the colonized by their colonial masters during the era of colonization; second, it is a reflection of the realities that independence brought about in the Empire." (p. 37)

It indicates that postcolonialism has a deeper meaning than an era after colonization. It is a study that tries to correct the stereotypical opinion towards colonized and a reflection of realities during the colonization. Klages (2006:147) then states that the field of post-colonialism examines the effect that colonialism has had on the development of literature and literary studies - on the novels, poems, and 'English' departments within the context of the history and politics of regions under the influence, but outside the geographical boundaries of England and Britain. In short, the use of term postcolonialism has a broader meaning. 


\section{Multatuli (Eduard Douwes Dekker)}

Multatuli is the name pen of Eduard Douwes Dekker, a famous writer form Dutch. He is well known for his satirical novel entitled Max Havelaar which exposed the abuses of colonialism happened in Dutch East Indies (today is known as Indonesia). The pen name Multatuli means "I have suffered so much" (from Latin words Multa Tuli). He was born in Amsterdam on March $2^{\text {nd }} 1821$ and died in Germany on February $19^{\text {th }} 1887$. When he lived, he had written many articles for newspapers and magazines in Dutch. He also wrote some plays, however his most memorable work is Max Havelaar. His memorable work made all the people in Dutch opened their eyes about the abuses of power happened in Dutch East Indies (Indonesia).

Although Multatuli is known as a famous writer, he was actually a Dutch civil servant assigned in Indonesia in 1838 until 1851. During the period between 1848 and 1851 he had assigned as assistant resident in some areas in Indonesia including North Sumatra, North Celebes (Manado) and Ambon. In 1857 he was transferred to Lebak, a residency in Java. In this time he openly began to protest about the abuses power of the colonial system since he knew all the secrets of Dutch administration. He saw the colonized suffered so much and faced many kinds of injustices. Knowing this fact, he tried to do the protests in order to fix the current conditions. As the consequences, he was threatened by his superiors and eventually made him resigned from his job. Later, he decided to return to Netherlands.

Although his protests as a civil servant were failed, his protests as a writer can be considered as a success. By the publishing of Max Havelaar, Multatuli opened the eyes of the people in Netherlands to see about how cruel the practice of colonialism happened in Indonesia that time. In his memorable work, Multatuli showed what kind injustices happened in Indonesia and the results for the colonized. Many colonized people in Indonesia suffered because of the colonialism done by the Dutch and Multatuli want to make the Dutch feel the same by providing them many sad stories happened in Indonesia. He also critiqued many policies done by the King and Dutch administration that caused the colonized people suffered so much. It showed us that Multatuli could feel the pains experienced by the colonized people and also tried to do something for the colonized in order to change the current conditions.

\section{Max Havelaar}

Max Havelaar is a novel written by Eduard Douwes Dekker under his pen name Multatuli. This novel is published in 1860 in Netherlands. This novel is written by Multatuli after serving Netherlands as a civil servant for 18 years in Indonesia (Dutch East Indies). This novel showed a great impact in changing the colonial policies made by Dutch and opened the eyes of the people in Netherlands about the abuses of power under the colonial system in the nineteenth and early twentieth century. This novel mainly tells about Max Havelaar, the protagonist, who tries to battle against a corrupt and cruel colonial government system in Lebak (a residency in Java).

In the preface of the novel (translated by Qanita Publishing in 2016), it is said that when Max Havelaar is first published in Netherlands in 1860, this novel caused a great effect and resulted many reactions. Max Havelaar exposed the abuses of power done by the corrupt Dutch government system. With a great enthusiasm, Multatuli provided this novel to the people in Netherland to show them the pains experienced by the colonized people in the Dutch East Indies (Indonesia). In Max Havelaar, Multatuli shows that the colonized people are the victims of colonial system done by the Dutch government. Multatuli also shows the struggles done by him when he was a civil servant in Lebak to end the cruel oppression happened daily in Lebak. Although many people say that Max Havelaar is only a good and intersting novel but Multatuli said many times in his novel that the content of the novel is the fact. It is proved by how brave 
Multatuli asked the Dutch Government for proving if there were mistakes in his book (can be seen in the last five pages in the book).

Every novel is written for a specific purpose or is caused by a particular reason. Max Havelaar written by Mulatuli is written to show a reality happen the Dutch East Indies at that time. Multatuli wrote this novel because of the disappointment felt by him towards the Dutch Government and the colonial system applied in Indonesia that time. Furthermore by this novel, Multatuli wanted to criticize about the abuses of power done by the Dutch government and local government. He showed to the reader about how the abuses of power done and about the practice of corruptions done by the Dutch and local government in Lebak at that time. He showed the reader about the tyranny happened in Indonesia and told the reader about how long they had closed their eyes towards the reality.

In general, Max Havelaar can be categorized as a novel which consists of many stories using two important points of views: Batavus Droogstoppel and the Young Stern which are the fictional characters made by Mulatuli (Multatuli, 2016). Stern in the novel had a role to tell about Max Havelaar and his struggles to fight the corrupt government. Droogstopple had a role to give comments during the stories told by Stern. It is funny to see that a fictional character made by Multatuli tell about a truth happened in reality (manifested in Max Havelaar as the protagonist character of the novel). Stern had a tendency to tell stories in the view of colonized people and Droogstopple had a tendency to give comments in the view of colonizers.

The novel is started by the stories about Batavus Droogstopple, a coffee broker. He is an example about a miserly and boring bourgeois. He is, as mentioned in the preface of the novel, the symbol of typical Dutchmen at that time and also the symbol of how Netherlands make a great profit by applying a cruel colonial system towards Dutch East Indies (Multatuli, 2016). The story about Max Havelar and his struggles is begun when his friend, Sjaalman, met Droogstopple and asked him for publishing Sjaalman's book.

Max Havelaar, the protagonist of the novel, is told by the Young Stern. Max Havelaar is the manifestation of the real experiences experienced by the Multatuli (Eduard Dowes Dekker) as the Dutch civil servant in Lebak, Banten. We have to note that Multatuli admitted that the stories of Max Havelaar are facts and really happen. Max Havelaar is described by Multatuli (in Stern's point of view) as a Dutch civil servant who fight for the rights of colonized people. However Havelaar's struggles to defend the rights of colonized people is opposed by his corrupt Dutch superiors who conspired with the local government. The conspiracies of Dutch government in Indonesia (Dutch East Indies) with local government is done in order to make a great profit for both sides by using the people in Lebak to do the forced labor. This story was actually based on the fact happened that time in the Dutch East Indies.

A very touching local story, story about Saidjah and Adinda is included in Max Havelaar. The romance story about Saidjah and Adinda is included in order to show people in Netherland about how bad and how cruel the impact of the colonial system applied in Dutch East Indies. Behind a very touching love story of Saidjah and Adinda there is an implicit accusation towards Dutch government about the exploitations and cruelties causing the people of Java as prime victims. In the last pages of the book, Multatuli accused King William III as the king of Dutch as the one who responsible for the cruelties happened in Dutch East Indies (Indonesia). He pointed that King William III is the one who responsible for the corrupt Dutch government in Dutch East Indies which caused the more than thirty millions people in Dutch East Indies had to face great pains and suffered so much because of the name of King William III.

At its first publication in 1860, Max Havelaar in no time caused a great controversy regarding the truth brought in the book and regarding the truth that has been hidden from the people in Netherlands (Multatuli, 2016). Some people thought that Max Havelaar is fiction but Multatuli had said that the content of the book is fact that really happened in Dutch East Indies. 
This book is still published until this time and has been translated in more than 40 languages. Furthermore, In Netherlands this book is still a required reading book in Netherlands national education system. In 1999, an Indonesian writer named Pramoedya Ananta Toer said in New York Times that Max Havelaar is the book that killed colonialism.

\section{Methodology}

Max Havelaar written by Multatuli indeed brought many themes such as struggles for colonized people, slavery, exploitations and cruelties of colonizer, forced labor, pain faced by the colonized and even romance. The themes then can be found in the novel and manifested in the stories in the novel. Based on the ideas brought in the novel, the characteristics of the novel and based on themes, this novel then can be categorized as a postcolonial literary work. Furthermore, this novel will be analyzed by using postcolonial theories as mentioned in the previous parts of this work. The theories used will take a roll as guideline in analyzing Max Havelaar however the theories will not dictate the writers in doing his analysis.

In constructing his analysis, the writer is still opened to every possibility in new findings. Some findings will be different with the theories used in the previous parts and some findings will be in accordance with the theories, however it is normal since a qualitative method is opened to every possibilities and new findings. The method also gives a great chance for the writers to find many new things related to the postcolonial literary works.

\section{The Discussion}

Max Havelaar $(\mathrm{MH})$ written by Multatuli is a unique literary work based on the narrative structure. If you have ever read $\mathrm{MH}$ you can see that two important points of view: the Young Stern and Batavus Droogstopple intercepted each other's stories. You can also found that MH consists of two main stories: 1) Story of Max Havelaar and his struggles to fight back the colonial system; and 2) The story about Batavus Droogstopple and his life in Dutch. Furthermore the uniqueness of $\mathrm{MH}$ can be seen when the main story of the novel: Story about Max Hevalaar is told by the fictional characters made by Multatuli, the Young Stern. In short, $\mathrm{MH}$ is a unique postcolonial novel.

Based on some theories as mentioned before we can see that postcolonial literature is believed comes from Britain's colonies in the Caribbean, Africa and India (www.decolonize.org). In addition, Abrams (1999) notes that postcolonial literature also comes from former colonies of Spain, France and other European imperial powers. However MH is not coming from a colonized country but published in colonizer countries. Coming from this fact, we can see that MH is very unique novel based on the place where it is published. However we have to note that the setting of the story, Dutch East Indies, is a colonized country. We have to understand that the place where the literary works is published did not play major role, the major role is played by the setting and the content of the story. The unique thing about $\mathrm{MH}$ is the author is a Dutchman; in this case he came from colonizers countries. It is unique because most of the postcolonial literary works were written by the writers of colonized countries. However it does not matter since the postcolonial literature "possesses a bi-partite nature. First, it is an intellectual movement that attempts to correct the stereotypical assumptions foisted on the colonized by their colonial masters during the era of colonization; second, it is a reflection of the realities that independence brought about in the Empire" (Bamghose, 2013: 37). In short, postcolonial literature does not emphasize on the writers' origin or where the work is published but emphasize on the content of the stories in order to bring the typical issues of postcolonial literature: slavery, colonialism, etc.

In $\mathrm{MH}$ we can see that Multatuli wanted to correct the stereotypical assumption about colonial system applied in Dutch East Indies (Indonesia). We can assume that many people in Dutch did not know the real reality in Dutch East Indies. They (Dutchmen) might think that the 
colonial system applied in Indonesia is fine because there are no reports about injustices, war, suppression, abuses of power, and violation of human rights. However in MH, Multatuli wanted to open their (Dutchmen) eyes that the reality is different with their assumption about the colonial system applied in Indonesia. Multatuli even explained the reason why the cruel reality in colonized country (Dutch East Indies) is hidden from people in Dutch. The quotation below explained why the reality in Dutch East Indies is hidden from many people in the Dutch and why they thought that everything was fine:

"Pada umumnya menyampaikan berita buruk sangat tidak menyenangkan, dan tampaknya seakan sebagaian dari kesan tidak menyenangkan ini melakat pada orang yang bertugas menyampaikannya...Pemerintah Hindia Belanda gemar menulis surat kepada majikan mereka di negeri Belanda, mengabarkan bahwa segalanya berjalan secara memuaskan." (p. 300 - 301)

"To bring bad news is generally disagreeable, and it seems as if something of this unfavourable impression to him whose lot it is to communicate them... The Government of Dutch India likes to write home to its master in the mother country that all goes on satisfactorily."

The quotation above explains the broad outline why the reality is hidden from people in Dutch. However the explanation does not stop there, the complete explanation can be read in $\mathrm{MH}$ until pages 304. In this case we can see that Multatuli tried to explain the reason why the reality is hidden and tried to correct the stereotypical assumption about the colonial system applied in Dutch East Indies (Indonesia). MH then fulfills the first nature of postcolonial literature: correcting the stereotypical assumption about the colonized country.

Based on its publishing year, MH which is published in 1860 shows its uniqueness. It is well known that the term postcolonial literature emerged in the late 1940s or we can say that the term postcolonial literature emerged after many colonized countries gained their independence. However we have to note that postcolonial literature had existed before the term postcolonial literature is used widely (Bamghose, 2013). It, once again, emphasize the idea that postcolonial literature is about the content and not about the publishing year. In simple assumption we can say postcolonial literature does not bound to the concept of where it is published and when it is published but bound to the content of the literary works. We have to note that MH is written based on Mulatuli's experiences when he was an assistant resident in Dutch East Indies for 18 years, $1838-1851$. He wrote the whole story of MH in 1859 in Belgium and then published it in 1960 in Dutch. In 1838 - 1851 Dutch East Indies is a country under Dutch colonial system, this fact then tells us that $\mathrm{MH}$ is written in colonialism period and reflects the conditions of colonized country. In short, $\mathrm{MH}$ as a postcolonial literary work is a consequence of colonialism and colonial system applied in Dutch East Indies.

As a postcolonial literary work, $\mathrm{MH}$ still preserves its main characteristic: the tendencies of writing back. The quotation used above describe that the news which came from Dutch East Indies is always good news. The report about real condition in Dutch East Indies is manipulated by the Dutch government in Dutch East Indies in order to make a good impression and to gain trust from the government in Dutch. The cruel reality that covered by fake good news and reports made all the people in the Dutch blinded by a "peace" fiction stories made by the Dutch government in Dutch Indies. Multatuli, based on his experiences, knew this fact and then tried to writing back the fact or I might say tried to correct this misunderstanding by publishing his book: Max Havelaar. He emphasizes this idea in the last pages of his book. The quotations bellow might be the evidences of Multatuli's efforts to correct the reality:

"Aku akan dibaca oleh para negarawan... dan oleh para anggota dewan perwakilan rakyat yang harus mengetahui apa yang terjadi di jajahan luas di seberang lautan yang menjadi milik Belanda ...." (p. 461 - 462) 
"I will be read by statesmen...by the members of the Representative Chambers, who must know what happens in the extensive possessions over the sea, which belong to Holland..."

"Justru inilah kehebatan bukuku: gagasan-gasan utamanya mustahil untuk dibantah... Aku bisa berlatih, dan mungkin, dengan sedikit upaya akan memperoleh keahlian yang bisa membuat rakyat mendengarkan keberanaran." (p. 462-463)

"For, the merit of my book is this: that refutation of its main features is impossible... I could exercise it, and perhaps, by dint of some exertions, attain to that skill which would make the truth heard by the people"

The evidences showed above show us that Multatuli tried to correct the stereotypical assumption regarding the real condition in Dutch East Indies. He wanted to tell his reader in Dutch that they are blinded by Dutch government in Dutch East Indies using fake good news and fictional reports. Based on the quotation above I might conclude that there are two reasons why Multatuli wants to correct the stereotypical assumption that time: 1) He felt the pains felt by the colonized people in Dutch East Indies; and 2) Restoring the Dignity of Dutch before it is too late. Before it is too late mean that before the quantity of victim increases; before Dutch is more hated by the colonized people in Dutch East Indies; and before Dutch is accused for many pains experienced by the colonized people in Dutch East Indies in the future.

The tendencies of correcting (writing back) the stereotypical assumption can be seen clearly in the story of Max Havelaar and his struggles to fight back the corrupt Dutch government and cruel local government when he was in Lebak. It also can be seen in the evidences provided above when he provide some contradictions about the real conditions and the assumptions believed by the people in the Dutch. By showing the contradictions, Multatuli wanted to open the eyes of the people in the Dutch that they are blinded by their government assigned in the Duthc East Indies. He wanted to make the people in the Dutch know that all the prosperities they felt for many years had caused many people in the Dutch East Indies suffered and even died in poor condition. He wanted to make them see the reality in the Dutch East Indies that they are suffered because the policies made by the government; and it is aggravated by the fact that the local government also involved in making the colonized people suffered. The ways how Mulatuli described the condition of colonized people as quoted in $\mathrm{MH}$ :

"Memang benar bahwa jumlah pemberontak berkurang karena kelaparan hingga kurus kering, sedangkan para pembajak bisa membela diri mereka sendiri.” (p. 463)

"It is true those rebels were reduced by starvation to skeletons, while those pirates could defend themselves."

“... dan lebih dari tiga puluh juta rakyat Anda nun jauh di sana harus diperlakukan dengan buruk dan mengalamai pemerasan atas nama anda?” (p. 465)

"... and that Thy more than thirty millions of subjects far away should be ill-treated and should suffer extortion by Thy name"

showed the people in Dutch how cruel the colonial system applied in the Dutch East Indies. The evidences above also show Dutch government in Dutch East Indies is the one who responsible for all the pain felt by the colonized people. Many colonized people died and suffered because of the colonial system and they have to face hunger when they have a land with a great fertility. They (the colonized people) are not treated as human but as a tool (slaves) to make prosperities in Dutch. The cruel descriptions made by Multatuli make the people in Dutch feel the pain felt by the colonized people, and it is what Multatuli wanted. In short, to make the reader feel the hardness during the Imperialism era the postcolonial writers tried to described the colonizers as the cruel one (Mohammadzadeh, 2010).

Another characteristic of postcolonial literary work, the concept of others, is also described perfectly by Multatuli in MH. It can be clearly seen in some comments told by 
Batavus Droogstopple when intercepting the story about Max Havelaar told by Stern. This characteristic, as described in Droogstopple character, shows us about how superior Dutch compare to the Dutch Indies. It also showed, in Droogstopple's point of view, the stereotypical assumption of Dutchmen about how superior their country and how superior their culture. Here some evidences in $\mathrm{MH}$ that described the concept of others:

“... Bukankah orang Jawa miskin? Mereka kafir. Semakin banyak orang Belanda berurusan dengan orang Jawa, semakin banyak kekayaan yang akan ada di sini, dan semakin banyak kemiskinan di sana." (p. 360 -361)

"... Are not the Javanese poor? They are Pagans. The more the Dutch have to do with the Javanese, the more wealth will be here, and more poverty there"

Oleh karena itu, bukankah dikatakan "berdoa dan bekerjalah”, yaitu kita harus berdoa dan menyuruh mereka yang tidak mengenal Doa Bapa Kami untuk melakukan pekerjaan? (p. 362)

"Is it not therefore 'Pray and labour,' that we should pray, and have the work done by those who do not know the Lodr's Prayer?"

The evidences provided above show the concept of others perfectly. All of quotations above are told in Droogstopple's point of view. So, what does it mean? The first, we have to note that Droogstopple as the character made by Multatuli are the reflection of typical people in Dutch. Second, the concept of others as reflected in Droogstopple character emphasizes on his superior viewpoints to himself. The last, the concept of others is also reflected in Droogstopple's narrative about how superior Dutch is and how inferior the people in Java are.

The three kinds of superiority as shown in evidences above describe the reason of colonialism in Dutch East Indies. Droogstopple as the portrait of typical Dutchmen shows us that the colonizers always think that their cultures and beliefs are more superior. These kinds of superiority crate an impression to us that the colonialism done by Dutch in Dutch East Indies can be justified because of the superior knowledge. Multatuli knows this fact very well: he used the character of Droogstopple who think himself and his nation are superior to criticize the fact that the superiority makes all the people in Java suffered and felt many pains. Multatuli then uses cause-effect way of thinking to describe how the superiority makes the people in Lebak suffered. In addition he also describes the concept of other by showing some contradictions to show how big the difference between the reality and the assumption they think about the condition in the Dutch East Indies.

The way Multatuli describes the concept of other in $\mathrm{MH}$, in my opinion, is unique. In general, postcolonial literary works tend to take sides on colonized point of view. However, Multatuli uses a unique way: he uses two important points of view (Stern and Droogstopple). Multatuli shows himself in colonized point of view by using the character of Stern and he also shows himself in colonizers point of view by using the character of Droogstopple. It makes an impression that Multatuli gives a freedom to his reader to choose the side they want to stand. But, in the last pages of $\mathrm{MH}$, Multatuli shows in which side he stands: the side of the colonized people. We also have to note that Multatuli provided the two points of view in MH to show the contradictions: how different the colonized and the colonizer see a phenomenon. In my opinion, by using this way (using two different points of view) he wants to bring around his reader in the Dutch to think about effect caused by the typical assumption. He wants to make them realize the effect of the superiority, and to make them realize how the superiority blind them. He also wants to show them that their superiority makes them lose their humanity and then makes the people in Java suffered so much and even died in very poor condition.

I have to admit that the way Multatuli described the concept of others in $\mathrm{MH}$ is perfect. The evidences above show it. We can see how Multatuli uses Droogstopple as a "religious" man to describe that a narrow understanding about God blinded many people. I think Multatuli 
wanted to criticize the role of religion. A religion, Chrisitian as told in $\mathrm{MH}$, as a place where people can understand God should tell its people to care each other. However in fact, Multatuli find the opposite: religion justified the wrong action caused by colonialism. It means that religion involves in making the people lose their humanity. It makes an impression to me that Multatuli wanted the religion, as a place where people can "find" God, guided its people "to be like God": loving each other, caring each other, helping each other and even feeling involved with the pain felt by others without looking the status, physical differences, ethnics, and races. I personally think that the message brought by Multatuli in $\mathrm{MH}$ is still relevant with the current condition where we live. Humanity should cut all differences through.

One characteristic of postcolonial literary work which can also be found in $\mathrm{MH}$ is alterity. In a simple definition we can define alterity as the condition where the culture of colonized and colonizers incorporate each other. Bamghose (2013: 36-37) even said, "Postcolonial literatures are as a result of this interaction between imperial culture and the complex of indigenous cultural practices." Coming from this idea, we can assume that postcolonial consists of culture assimilation. We can see this fact in language feature of the literary works or by looking at the way how the writer describes the setting and even the tendencies of the writer in writing the literary work. In $\mathrm{MH}$ we can see the concept of alterity perfectly. For example you can see the poem written in French on page 250 or the poem written in German on page 312 until page 316 or the poem written in German (Auf Flugeln des Gasenges written by Heinrich Heine) on page 202. Now, there is a question: why do Multatuli have to use many kinds of language in $\mathrm{MH}$ ? I think there are two possible answers regarding the question asked before. 1) It shows how Multatuli understand many kinds of culture and to create an impression about "how smart he is." However I think this answer is my assumption because I really amazed by the way Multatuli used many languages to describe a particular moment. 2) By using a certain language he wanted to make his reader felt a particular impression about a moment in $\mathrm{MH}$. For example when he uses a poem written in German on page 202, he wanted to make impression to his reader - that the character of Stern looked so real, since it is told in MH that the Young Stern came from Poland and understand many German literature. By using a famous poem written in German he wanted to make the character in $\mathrm{MH}$ looked so real.

The concept of alterity in MH might be understood differently. In general we can say that the concept alterity is limited to the assimilation of cultures as described in the setting of the novel or the language used in the novel. For example, some postcolonial novels which came from Africa are written in English and not in their native language as an indication of alterity. However in $\mathrm{MH}$, the alterity is not only limited on language use. Multatuli described the concept alterity by inserting some literary works from other countries or written by another author. Some of notable literary works written by another author used by Multatuli in MH are Auf Flugeln des Gasenges written by Heinrich Heine on page 202; and the story about Stone Carver written by Wolter Robert van Hoëvell on pages 231 - 234 - Published on Tijdschrift voor NederlandschIndie (Journal of the East Indies) in 1842. By inserting the literary works of another author in MH, Multatuli shows how genius he is in arrange a story. I am so amazed to see how he could combine other literary works in $\mathrm{MH}$ make it looked "so smooth" in the transition of the sequence events in $\mathrm{MH}$.

The concept of alterity in $\mathrm{MH}$ is also shown by the way Multatuli composed two poems (you can see in appendix of the novel) in Malay language. It shows us the experiences of Mulatuli when he was in Dutch East Indies. He made the poem in Malay language to make the reader feel that the event in MH is really happened. Furthermore these poems were inserted in the story of Saidjah and Adinda which we can assume by the names are native people of Dutch East Indies. I personally think that the concept of alterity as described in $\mathrm{MH}$ is not just the effect of assimilation of culture but emphasize more on the idea to make the reader feel that the characters and the events in $\mathrm{MH}$ looked real and alive. These facts then show us that $\mathrm{MH}$ is not 
just an ordinary postcolonial literary work. In my opinion the concept of alterity in $\mathrm{MH}$ show how talented Multatuli in arranging a great story. In short, alterity as described in MH have to be understood differently with the general concept of alterity in other postcolonial literary works.

As you can see, $\mathrm{MH}$ does not fulfill one characteristic of postcolonial literature: question about identity. The question about identity usually comes from the literary works written by the colonized writers. It is also can be found in the literary works published after the colonized countries gained their independency in order to make the reader love their country. However, $\mathrm{MH}$ is not written to make the reader love their country or to bring the idea of question about identity. I think $\mathrm{MH}$ is written to criticize the colonial system applied in Dutch East Indies. Multatuli wanted to criticize the policies makers who cause many people in Dutch East Indies suffered so much. Multatuli wrote MH in order to open the eyes people in the Dutch about the reality happened in Dutch East Indies. He wanted to move their humanity side and to tell them that they are blinded for so long by their government in Dutch East Indies. Furthermore, Multatuli wanted to correct the condition and stereotypical assumption in the Dutch at that time. $\mathrm{MH}$ is also Multatuli struggles to help the people in Dutch East Indies as he had promised to help them. In short, Multatuli in $\mathrm{MH}$ emphasizes more the first characteristics of postcolonial literary works: the tendencies of writing back or correcting the stereotypical assumption in the Dutch at that time: Everything in Dutch East Indies is fine as in Dutch.

However, after reading MH I found another characteristic of postcolonial literary work which is not mentioned in the previous part of this work. It is the power to evoke readers' sense of humanity. I think this characteristic is closely related to the first characteristic. Simply we could think that in order to correct the stereotypical assumption of the people in the Dutch MH had to have the power to evoke the Dutchmen's sense in humanity. If MH cannot evoke their sense of humanity, $\mathrm{MH}$ will just be an ordinary novel. But in reality $\mathrm{MH}$ have proved that it can evoke their sense of humanity. However, we have to note that not all postcolonial literary works have this characteristic. This characteristic can be seen clearly in chapter 17 when Multatuli told the story about Saidjah and Adinda. By showing this romantic-tragedy story Multatuli succeed in moving heart of many people, he succeed in evoking their sense of humanity and succeed in making them open their eyes to the cruel reality happened in the Dutch East Indies. The message Multatuli wanted to deliver to his reader is "colonialism just made many people and even could separate the person destined for each other." I think Multatuli understood his reader well by using romantic-tragedy story to evoke their sense of humanity. By using romantic-tragedy story about Saidjah and Adinda, he wanted to touch the deepest part of his readers' heart. It then makes his readers evoke their sense of humanity.

The great impact made by MH is its succeeding in opening the eyes of the people in the Dutch. It then caused many movements in Dutch which asked Dutch Government for accepting the responsibility for the welfare in the Dutch East Indies. The movements then made Dutch Government under the reign of Queen Wilhelmina in 1901 launched Dutch Ethical Policy. Dutch Ethical Policy then erased the cultivation system (cultuurstelsel) and responsible for educating the elites of Dutch East Indies. The educated elites then created many national organizations that evoke the sense of nationality of the people in the Dutch East Indies. The national organizations with the people of the Dutch East Indies then fight back the colonizers to gain their independency. Their efforts to gain the independency then succeed to bring the independency for Indonesia (Dutch East Indies). It shows how important the role of MH for the independency of Indonesia. So it is logic when Pramoedya Ananta Toer said that Max Havelaar is the book that killed colonialism.

\section{Conclusion}

After reading Multatuli's Max Havelaar and after conducting an analysis regarding its content there are some things can be concluded. First, Max Havelaar which is published in 1860 
in Netherland looked like not a postcolonial literary work considering the publishing year and the place where it is published. However after reading the content of the novel I can conclude that this novel is a postcolonial work because the content and the message brought in Max Havelaar describe the postcolonial spirit perfectly. It can be seen clearly when Multatuli in Max Havelaar tried to criticize the colonial system applied in Dutch East Indies. Second, Max Havelaar is indeed a postcolonial literary work since it fulfills three of four postcolonial works' characteristics: tendencies of writing back, the concept of others, and alterity. Although Max Havelaar does not fulfill all characteristics of postcolonial works, it still can be categorized as postcolonial works because postcolonial spirit is not limited to the characteristics or period. The last, Max Havelaar as a postcolonial work has a unique and strong characteristic: The ability to evoke people's sense of humanity. This characteristic can be seen clearly by seeing the effects caused by the publishing of Max Havelaar for the people in the Dutch (colonizer) and for the people in the Dutch East Indies (colonized).

\section{Bibliography}

Abrams, M. H. (1999). A Glossary of Literary Terms (Seventh Edition). US: Heinle \& Heinle Thomson Learning.

Ashcroft, B., Griffiths, G., and Tiffin, H. (2007). The Postcolonial Studies: The Key Concepts (Second Edition). London: Routledge.

Bamghose, G. S. (2013). The Black Man's Ordeals: A Postcolonial Reading of Kofi Anyidoho's Ancestrallogic and Caribbeanblues. The African Symposium: An Online Journal of the African Educational Research Network, Vol. 13, No. 1, pp. 34-41.

Boehmer, E. (1995). Colonial and Post-colonial Literature. Oxford: Oxford University Press.

Childs, P. and Fowler, R. (2006). The Routledge Dictionary of Literary Terms. New York: Routledge.

Cuddon, J. A. (2013). A Dictionary of Literary Terms and Literary Theory. John Wiley and Sons, Ltd.

Dizayi, S. A. H. (2015). The Crisis of Identity in Postcolonial Novel. INTCESS15- 2nd International Conference on Education and Social Sciences, pp. 999-1007 (Istanbul, 2 4 February 2015). (in http://www.ocerint.org/intcess15_e-publication/papers/575.pdf)

Drabble, M (ed). (2000). The Oxford Companion to English Literature (Sixth Edition). New York: Oxford University Press Inc.

Fatima, A., Jamil, A., and Hanif, S. (2015). Othering of Africans in European Literature: A Postcolonila Analysis of Condrad's "Heart of Darkness. European Journal of English Literature Studies. Vol. 3, No. 5, pp. 40-45.

Golden, A. (2015). A Brief History of Postcolonial Literature, Part I, uploaded on April $19^{\text {th }}$ 2015 at 09.00 A.M. in https://blog.bookstellyouwhy.com/a-brief-history-of-postcolonialliterature-part-i (Accessed on March, $13^{\text {th }}$ 2017, at 10.27 p.m.)

Griffith, K. (1986). Writing Essays about Literature (2 ${ }^{\text {nd }}$ Edition). USA: Harcourt Brace Jovanovich, Inc.

Guven, S. (2013). Postcolonial Analysis of Joseph Conrad's Heart of Darkness. Journal of History Culture and Art Research. Vol. 2, No. 2, pp. 79-87.

Hamadi, L. (2014). Edward Said: The Postcolonial Theory and the Literature of Decolonization. European Scientific Journal. Vol. 2, pp. 39 - 46.

Kenalemang, L. M. (2013). Things Fall Apart: An Analysis of Pre and Postcolonial Igho Society. Karlstads Universitet. (In http://www.divaportal.org/smash/get/diva2:648320/fulltext01.pdf).

Khanal, N. (2012). The Lens of Postcolonial Theory in LIS Research and Practice. Dissertation in 
https://www.ideals.illinois.edu/bitstream/handle/2142/42338/Navadeep_Khanal.pdf?sequ ence $=1)$

Klages, M. (2006). Literary theory: A guide for the perplexed. London: Continuum.

Maru, Mister Gidion (2013). Puritanism in American Presidents 'Mark of Power: A Study on The Inaugural Addresses from Reagan to Obama. Yogyakarta: UGM Dissertation

Multatuli. (2016). Max Havelaar (Translated by Ingrid Dwijani Nimpoeno - Qanita Team). Bandung: Qanita

Mohammadzadeh, B. A. (2010) Postcolonial Discourse In the God of Small Things by Arundhati Roy. 38. ICANAS, Vol, III, pp. 1023 - 1025 (http://www.ayk.gov.tr/wpcontent/uploads/2015/01/MOHAMMADZADEH-Behbood-A-POSTCOLONIAL-DISCOURSEIN-THE-GOD-OF-SMALL-THINGS-BY-ARUNDHATI-ROY.pdf)

Mondal, A. (2014). Postcolonial Theory: Bhabha and Fanon. International Journal of Science and Research, Vol. 3, Issue II, pp. 2965-2968.

Powell, J (ed). (2004). Dictionary of Literary Influences: The Twentieth Century, 1914-2000. London: Greenwood Press.

Roy, A. (2008). Postcolonial Theory and Law: A Critical Introduction. Adelaide Law Review, Volume 29, Number 2, pp. 315-358.

Shohat, E. (1992). Notes on the "Post-Colonial". Social Text, No. 31/32, Third World and Postcolonial Issues, pp. 99-113.

Tepeciklioglu, E. C. (2012). The Development of Postcolonial Theory. $4^{\text {th }}$ ECPR Graduate Students Conference Jacob University (Bremen, 4- 6 July 2012). (in https://ecpr.eu/Filestore/PaperProposal/3b9bec0c-08fa-4de4-bfea-b6ec2fca976e.pdf)

Tiffin, H. (2003). Postcolonial Literatures and Counter Discourses. In Ashcroft, B., Griffiths, G., and Tiffin, H. (eds.). The Postcolonial Studies Reader (Third Edition). London: Routledge. (pp.95-98)

Vogel, D. (2012). Joseph Conrad in the Light of Postcolonialism. Yearbook of Conrad Studies (Poland), Vol. VII, pp. 97-112.

Waqar, B. (2016). Repossessing Home: A Postcolonial Study of the Schooner Flight by Derek Walcott. Journal of Research (Humanities), Vol. LII, pp. 113-131.

Other electronic sources:

Gann, K. (2012). Literature as a Mirror. Uploaded by Kyle Gann on July $14^{\text {th }} 2012$ in www.artsjournal.com/postclassic/2012/07/literature-as-a-mirror.html (Accessed on June, $1^{\text {st }} 2017$, at 10.31 p.m.)

(2015). An Introduction to Post-colonialism, Post-colonial Theory and Post-colonial Literature. Uploaded by admino on May $28^{\text {th }} 2015$ in www.decolonize.org/wpcontent/uploads/.../an-introduction-to-postcolonialism.pdf (Accessed on March, 13 ${ }^{\text {th }}$ 2017, at 10.31 p.m.)

Postcolonialism in https://en.wikipedia.org/wiki/Postcolonialism (Accessed on March, 13 ${ }^{\text {th }}$ 2017, at 09.22 p.m.) 